\begin{tabular}{ll}
\hline & $\begin{array}{l}\text { Kastamonu Eğitim Dergisi } \\
\text { Kastamonu Education Journal }\end{array}$ \\
$\begin{array}{l}\text { Ocak } 2019 \text { Cilt:27 Sayı:2 } \\
\text { kefdergi.kastamonu.edu.tr }\end{array}$ & Başvuru Tarihi/Received: 30.01 .2018 \\
Kabul Tarihi/Accepted: 02.06 .2018 \\
Dol: $10.24106 /$ kefdergi.2618
\end{tabular}

\title{
Sosyal Bilgiler Öğretmenlerinin Öğretme Stillerinin Çeşitli Değişkenler Açısından İncelenmesi (Muğla ìli Örneği)'1
}

\section{Investigation of Teaching Styles of The Social Studies Teachers With Respect to Several Variables (Example of The Mugla Province)}

\section{Öz}

\author{
Ayşe TOSUN², Zafer TANGÜLÜ3
}

Bu çalışmada sosyal bilgiler öğretmenlerinin öğretme stilleri tespit edilerek; çeşitli değiş̧kenlere göre incelenmeye çalışılmıştır. Araştırma tarama modeli kullanılarak gerçekleştirilmiştir. Çalışmaya 2016-2017 yılı Muğla ilı Milli Eğitim Müdürlüğü bağlı ortaokulların 5., 6. ve 7. sınıflar da görevli toplam 165 öğretmen dahil olmuştur. Çalışma verilerini toplamak için kişisel bilgi formu ve Grasha öğretme stili ölçeği kullanılmıştır. Ölçekteki veriler SPSS programı kullanılarak çözümlenmiştir. Yapılan istatistiksel analizler sonucunda Sosyal bilgiler öğretmenlerinin \% 48,5 ile en fazla rehber öğretme stilini benimsediği görülmüştür. Ayrıca; mesleki kıdeme, sınıf mevcudu, hizmet içi eğitim ve sınıf düzeyi değişkenlerine göre bazı öğretme stilleri arasında anlamlı bir farklılık olduğu bulunmuştur.

Anahtar Kelimeler: Sosyal bilgiler, öğretme, öğretme stilleri

\section{Abstract}

This study, the teaching styles of Social Studies teachers are determined; have been tried to be analyzed according to various variables. The research was conducted using a screening model. Total 165 teachers working at the 5th, 6th and 7th grades of the secondary schools of the Muğla Provincial Directorate of National Education for the academic year of 2016-2017. The personal information form and the Grasha teaching style scale were used to collect the study data. SPSS program was used to analyse the data in the scale. As a result of the statistical analyses, $48,5 \%$ of the Social Studies teachers were found to prefer the guide teaching style. Also; it is found that there is a significant difference between some teaching styles according to the variables such as professional seniority, classroom availability, in-service training and class level.

Keywrods: Social studies, instruction, teaching styles

1. Bu çalışma ilk yazarın ikinci yazar danışmanlığında hazırlamış olduğu yüksek lisans tezi kapsamında oluşturulmuştur.

2. Anadolu Üniversitesi, Eğitim Bilimleri Enstitüsü, Eskişehir, Türkiye; https://orcid.org/0000-0003-4813-3470

3. Muğla Sıtkı Koçman Üniversitesi, Eğitim Fakültesi, Muğla, Türkiye; https://orcid.org/0000-0003-1596-442X

Atıf / Citation: Tosun, A., \& Tangülü, Z. (2019). Sosyal bilgiler öğretmenlerinin öğretme stillerinin çeşitli değişkenler açısından incelenmesi (muğla ili örneği). Kastamonu Education Journal, 27(2), 621-631. doi:10.24106/kefdergi.2618 


\section{Extended Summary}

Today, a result of the rapid changes in social, political, economic and cultural areas of information are constantly increasing in a short time and are constantly being renewed in a new motion. There are a number of changes and innovations to keep up with the time in the world of the 21st century, to acquire the knowledge, skills and values required by the age, to ensure the continued quality of learning in the field of education. Especially, when we look at the present teaching concept is understood that is much more complex than the stimulus-response context behavioral understanding of the learning and will not achieve the main objectives with "direct teaching" on the behalf of qualified learning.

Grasha, during their studies on the learning styles has classified into 10 groups by taking into account teacher's attitudes, self-efficacy perceptions, qualifications brought by the profession, teacher-student interaction and teaching processes Grasha has divided according to five different styles learning styles teachers by building on these 10 behaviors teaching styles. Piaget express that while student are succesful mathematics and so, on the reasons for the failure in other subjects, the lesson is not the comprehension, but the form of the course. In brief, the realization of effective learning on students depends on the well-organized teaching process. Especially, it is important the process of teaching a lesson which contains many disciplines, verbal information such as social studies lesson. Because, unless the teaching phase of the social studies course is made meaningful for the students, the information will be memorized and will likely be forgotten shortly. For this reason, social studies education should be directional and should improve yourself in the direction of innovations by becoming aware of its teaching.

With this study, by determining the teaching style of social studies teachers; this study aims to examine in regards to gender, vocational grade, classroom availability, in-service training attendance, social studies class and class level variables. The research was carried out using a relational screening model.

The study population consisted of 343 Social Studies teachers and 165 Social studies teacher responded to the questionnaire. In this context, the rate of return obtained in the study was $48 \%$.

In this study, in order to determine the personal information of Social Studies teachers "Personal Information Form" which was developed by the researcher was used. In addition, "Grasha Teaching Styles Scale" was used to determine teachers' teaching style preferences.

In the analysis of the data, non-parametric analyzes were used. Acquired datas were analyzed by Statistical Package for Social Sciences (SPSS 22.0) packaged software. According to the first sub-problem of the study preferred the guide teaching style of $48.5 \%$ of the teachers participated in the study.

Accordingly, teachers included in the study preferred more than half of the teachers' guidance teaching styles. The high level of this teaching style indicates that teachers create a collaborative and student-centered classroom environment in the classroom environment. According to gender in accordance with the findings of the second sub-study of the research, it was understood that the preference among male and female teachers was mostly guidance-teaching style. According to this teachers have the highest frequency in the style with student-centered approach. When the distribution according to occupational seniority in the study was examined, teachers with experience of "0-5", "6-10", "11-15" and " 21 and over" preferred the most guiding teaching style. According to class variables, teachers who were between " $5-15$ students" and "16-25 students" had the most preference for guidance teaching style. According to participate in in-service training of social studies teachers, it has been observed that teachers of social studies who have participated in and do not participate in in-service training the most prefer the guiding style of teaching. The teachers of social studies lesson and non-teacher preferred the guideline teaching style. As the class level gets higher, teachers prefer student centered styles. According to the third sub-problem of the research, it is seen that there is no difference in terms of ranking scores teaching style of male and female teachers. According to professional rank, a significant difference between the teachers' the expert teaching style and the advisor teaching style preferences was found. According to class size, a significant difference between the classroom variable and the expert teaching style, the authoritarian teaching style, and the advisor teaching style was found. According to the social studies classroom, it is found that there is no significant difference between the teaching styles. According to the class size, only a significant difference between the personal model teaching style was found. From the point of the research, it has been suggested by the Ministry of National Education that teachers can organize in-service training programs in terms of their clear concept of teaching-learning process. 


\section{Giriş}

Günümüzde değişimin hızı olması sonucu sosyal, siyasal, iktisadi ve kültürel alandaki bilgiler kısa sürede yayılarak artmakta ve bir devinim halinde sürekli yenilenmektedir. Özellikle bu süreçlerin yansıması olarak eğitim-öğretim anlayışına baktığımızda nitelikli bir öğrenme adına "doğrudan öğretim" (Woolfolk, 1998) ile asıl hedeflere ulaşılamayacağı ve öğrenmenin davranış̧ı anlayışın uyarıcı-tepki bağından çok daha karmaşık olduğu anlaşılmıştır. Bu zamanla eğitim sistemlerine de yansımış ve mutlak bilginin aktarılmasından öte değişen, gelişen bilginin nasıl ve hangi yöntemle kazandırılması gerektiği sorusunu gündeme getirmiştir.

Öğrenme üzerine yapılan araştırmalar zamanla öğretmeyi de önemli kılmıştır. Çünkü bireyin sahip olduğu stili aktif kılan ve etkili kılabilecek olan kişi öğretmendir. Bu sebeple öğrenme sürecinde bireysel farklılıkların varlığı kabul edilerek öğretim sürecinin düzenlemesi önemli olmaktadır (Maden, 2012). Öğretmenlerin ders esnasındaki öğretme farklııklarını vurgulayan araştırmalar sonuç itibariyle öğretme stili kavramını popüler hale getirmiştir (Üredi ve Üredi, 2007). Bu süreç devamında öğretme stiline ilişkin birçok tanım ve model oluşturmuştur. Grasha (2002) öğretme stilini öğretmenlerin öğretme aşamasında sürekli ve tutarlı olarak gösterdikleri davranışlar şeklinde yorumlamıştr. Üredi (2006) öğretmenlerin öğrencilere bilgiyi nasıl aktardığı, öğrencilerle nasıl etkileşimde bulunduğu, öğrencileri nasıl sosyalleştirdiğine ilişkin davranışları öğretme stili olarak ifade etmiştir.

Grasha (1994a) öğrenme stillerine üzerine yapmış olduğu çalışmalar esnasında öğretmenlerin sınıf ortamında sergilemiş oldukları tutumları, öz-yeterlik algıları, mesleğin getirmiş olduğu nitelikleri, öğretmen-öğrenci etkileşimini ve öğretim süreçlerini göz önüne alarak öğretmen davranışlarını 10 grupta sınıflandırmıştır (Gencel, 2013; Süral, 2013). Öğretme stillerini bu 10 davranış üzerine inşa ederek öğretmenleri beş farklı stile göre ayırmıştır. Grasha göre öğretmenlerin sınıf ortamındaki öğretimi, tutumu ve davranışı beş öğretme stilinden sadece birine uymasa da bir ya da birkaç alana ait özellikler diğerlerine göre üstün olabilmektedir (Grasha, 2002). Grasha (1996) kolej öğrencileri ve öğretmenleri ile yürüttüğü çalışmanın analizleri sonucunda öğretmenleri uzman, otoriter, kişisel model, rehber ve danışman olarak beş kategoriye ayırmıştır (Süral, 2013). Öğretme stillerine göre öğretmen özellikleri şu şekildedir:

Uzman / bilgi aktarıcı öğretme stili: Bu stilde öğretim süreci öğretmen merkezlidir (Grasha ve Yangarber-Hicks, 2000). Bilginin esas kaynağı olan öğretmen öğrenci karşısında uzman konumunu korumaya çalışır (Grasha, 2002). Öğrencilere kavramları ve ilkeleri kazandırmak önemlidir (Mutluoğlu, 2012). Bu stilde öğretmen öğrencilerin bireysel farklılıklarını dikkate almaz (Grasha, 2002).

Otoriter öğretme stili: Bu stildeki öğretim süreci öğretmen merkezlidir (Grasha ve Yangarber-Hicks, 2000). Öğretmen öğrencilere karşı mesafeli bir tutum sergileyerek öğrencinin ilgi ve ihtiyaçlarını göz önüne almaz (Süral, 2013). Bu stilin uzman öğretim stiline göre en belirgin farkı, öğretmenin kurallara daha çok bağlı olması ve öğrencilerine dönüt veren bir yapıya sahip olmasıdır (Süral, 2013).

Kişisel model öğretme stili: Bu stilde öğretmen öğrenci için bir rol model olmaktadır. Öğrencilerine öğrenme sürecine rehberlik eder ve gözlem yapmalarını destekler (Grasha, 2002). Öğretimi görsel ve işitsel açıdan destekleyerek kendi hayatlarından da örnekler verirler. Ders sürecinde öğrenciyi aktif kılar ve onların belirli sorumlulukları üstlenmelerini bekler (Şahin, 2010).

Rehber / kolaylaşttrıcı / yol gösterici öğretme stili: Bu stildeki öğretim süreci öğrenci merkezlidir. Öğretmen öğrenci ihtiyaçlarını göz önüne alır ve onlarla olan iletişiminde doğallığa önem verir. Öğretmen öğrencileri düşünmeye sevk ederek öğrenmede sorumluluk almalarına yardımcı olur (Üredi, 2006). Bunun içinde proje çalışmalarının olduğu işbirlikli öğrenme ortamı oluşturulur (Gencel, 2013).

Danışman / temsilci öğretme stili: Bu stilde öğrencinin merkeze alındığı öğretim süreci vardır. Öğrenciler kendilerini bağımsız öğrenenler olarak algılar, lakin öğrencilerin akademik düzeyleri ve becerileri bazen yanlış tespit edilebilir ve öğrenciler bağımsız davranış ve düşünme için gerekli yeteneklere sahip olmayabilir. Bu durum öğrencide kaygıya sebebiyet verebilir (Bilgin ve Bahar, 2008).

Piaget (1993) öğrencilerin matematik vb. derste başarılı olurken diğer derslerde başarısız olmasındaki sebebi dersin özünü kavrayamaması değil dersin veriliş biçiminden kaynaklandığını ifade etmiştir. Kısacası öğrenciler üzerinde etkili bir öğrenmenin gerçekleşmesi öğretim sürecinin iyi düzenlenmesine bağlı olmaktadır (Aktan, 2012). Özellikle Sosyal bilgiler dersi gibi birçok disiplini içinde barındıran ve yapısı gereği fazla sözel bilgiyi ve kavramı içeren bir dersin öğretme süreci önemli olmaktadır. Çünkü sosyal bilgiler dersinin öğretme aşaması öğrenciler için anlamlı hale getirilmedikçe bilgiler ezberlenecek ve büyük bir olasılıkla kısa bir süre sonra unutulacaktır (Erden, 1996). Bu sebeple Sosyal Bilgiler öğretmeni öğretme ortamında yakınsak düşünmenin ötesinde çok yönlü olmalı ve öğretiminin farkına vararak yenilikler doğrultusunda kendini geliştirmelidir (Erdoğdu, 2010).

Öğretme stillerine ilişkin yurtiçi ve yurtdışında yapılmış olan çalışmalara baktı̆ı̆ızda genel itibariyle ilköğretim, 
ortaöğretim ve yükseköğretimde görevli olan öğretmenlerin tercih ettikleri öğretme stillerinin çeşitli değişkenlere göre belirlendiği (Altay, 2009; Artvinli, 2010; Corcoran, 1997; Grasha, 1994b; Demir, 2015; Maden, 2012; Şahin, 2010; Valerie, 2006), öğretme ve öğrenme stilleri ile akademik başarılarının incelendiği (McGowan, 2008; Şentürk ve íkikardeş, 2011), öğretme stilleri ile öğretmen veya öğrenci algıları, inançları, özyeterlilik düzeyleri ve kaygılarının incelendiği (Coldren ve Hively, 2009; Dilekli, 2015; Ekici ve Kaya, 2017; Kaleci, 2013; Üredi ve Üredi, 2007; Sarı ve Aksoy, 2016; Saracaoğlu, Karademir, Dinçer ve Dedebali, 2017) çalışmalara rastlanmaktadır. Öğretme stillerine ilişkin literatür taramasında çalışmalar çeşitlilik göstermesine rağmen ülkemizde sosyal bilgiler eğitiminde öğretme stillerine yönelik çalışmalar yetersiz kalmaktadır. Öğretmenler sadece alan bilgisi ile sınırlı kişiler olmayıp öğretme stilleri açısından öğrenme ortamlarını düzenlemede, programın amaç ve hedeflerini gerçekleştirmede önemli bir etken olmuştur. Bu sebeple çalışmada sosyal bilgiler öğretmenlerinin öğretme stilleri incelenerek ilköğretim programı doğrultusunda niteliklerinin ne düzeyde olduğunun belirlenmesi bakımından önem taşımaktadır.

\section{Araştırmanın Amacı}

Bu çalışmanın amacı Sosyal Bilgiler öğretmenlerinin öğretme stillerini tespit ederek; cinsiyet, mesleki kıdem, sınıf mevcudu, hizmet içi eğitime katılma durumu, sosyal bilgiler dersliği ve sınıf düzeyi değişkenlerine göre incelemektir.

\section{Araştırmanın problemi}

Çalışmanın amacı ve problemi doğrultusunda aşağıdaki alt problemlere yanıt aranmıştır:

- Sosyal bilgiler öğretmenlerinin baskın öğretme stilleri dağılımı nasıldır?

- Sosyal Bilgiler öğretmenlerinin bazı demografik değişkenler (cinsiyet, kıdem, hizmet içi eğitim, sınıf mevcudu, derslik durumu ve sınıf düzeyleri) ile öğretme stilleri arasında istatistiksel olarak anlamlı bir farklılık var mıdır?

\section{Yöntem}

Araştırma Sosyal Bilgiler dersi öğretmenlerinin tercih etmiş oldukları öğretme stillerinin cinsiyet, mesleki kıdem, sınıf mevcudu, hizmet içi eğitim, sosyal bilgiler dersliği ve sınıf düzeyi değişkenlerine göre frekans ve önem durumunu belirleme açısından, genel tarama modeli kullanılarak gerçekleştirilmiştir. Genel tarama modeli; geçmişte veya halen var olan bir durumu olduğu biçimde tasarlamayı amaçlayan araştırma yaklaşımlarıdır (Karasar, 1999).

\section{Araştırmanın Evren ve Örneklemi}

2016-2017 yılı Milli Eğitim Bakanlığı Muğla İl ve İlçe Milli Eğitim Müdürlüklerine bağlı ortaokulların 5., 6. ve 7. sınıflarında görevli toplam 343 Sosyal Bilgiler öğretmeni bulunmaktadır. Araştırmada olasılıksız örnekleme yöntemlerinden rastgele örnekleme yöntemi kullanılmıştı. Buna göre araştırma evrenini oluşturan 343 Sosyal Bilgiler öğretmeninden 165 'i anketi cevaplamıştr. Geri dönüş oranı \% 48'dir olmuştur. Araştırmada öğretme stilleri anketi uygulanan öğretmelerin demografik özelliklerine göre dağılımı Tablo 1'de sunulmuştur.

Tablo 1. Sosyal bilgiler öğretmenlerinin demografik özellikleri

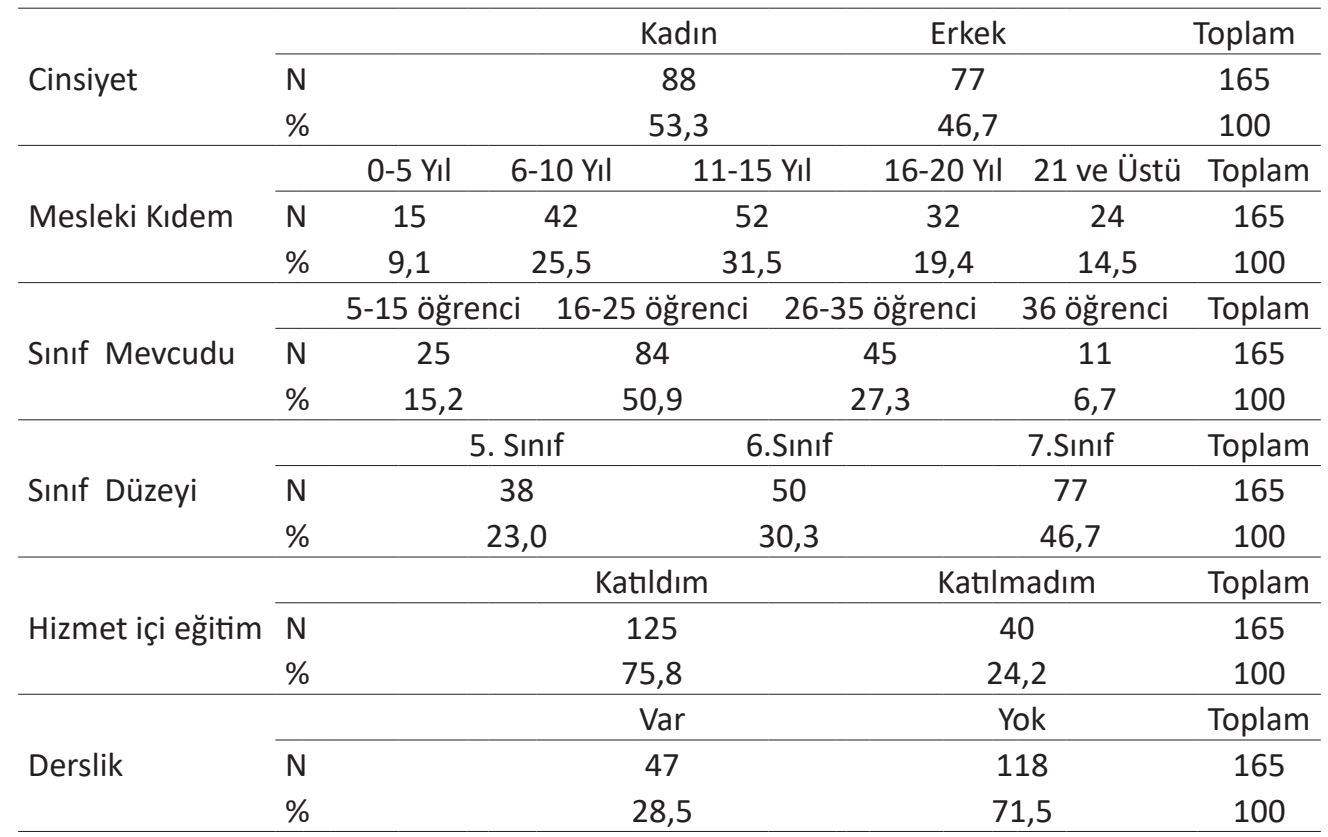


Tablo 1'e göre öğretmenlerin \% 53'ü kadın \% 46'sı erkektir. Mesleki kıdeme göre 11-15 yıl arasında çalışan öğretmenlerin \%31,5 ile en fazla, 0-5 yıl aralığında çalışan öğretmenlerin de \% 9,1 ile en az olduğu görülmektedir. Sınıf mevcuduna göre, 16-25 öğrencisi olan öğretmenlerin \% 50,9 ile en yüksek orana sahip olduğu anlaşılmaktadır. Öğrenci sayısı 36 ve üstü olan öğretmenler ise \% 6,7 ile en az orana sahiptir. Sosyal bilgiler dersliğine göre öğretmenlerin \% 71,5'inde derslik mevcut değildir. Öğretmenlerinin \% 75,8'i hizmet içi eğitime katlırken, \% 24,2'sinin hizmet içi eğitime katılmadığı anlaşılmıştır. Araştırmaya dâhil olan öğretmenlerin \%46,7 oranıyla en fazla 7.sınıflara, \% 30,3'nün 6. sınıflara ve \%23'ünün de 5 . sınıflara girdiği görülmüştür.

\section{Verileri Toplama Araçları}

Araşttrmada Sosyal Bilgiler öğretmenlerinin kişisel bilgilerini belirleyebilmek için araştrmacı tarafindan oluşturulan "Kişisel Bilgi Formu" kullanılmıştır. Formda öğretmen cinsiyet, mesleki kıdem, sınıf mevcudu, sosyal bilgiler dersliği, hizmet içi eğitime katılma durumu, sınıf düzeyi gibi bilgilere yer verilmiştir. Ayrıca öğretmenlerin öğretme stili tercihlerini tespit edebilmek için "Grasha-Riechmann Öğretme Stilleri Ölçeği” kullanılmıştır.

\section{Grasha-Riechmann Öğretme Stili ölçeği}

Grasha, öğretmenlerin inanışlarını, bilgilerini ve davranışlarını sınıfa yansıttı̆ı̆ı savunarak "Grasha-Riechmann Öğretme Stilleri Ölçeği"ni geliştirmiştir (Babadoğan, Kassenova ve Karaşahinoğlu, 2014). Araşttrmada Grasha-Riechmann (1996) tarafindan geliştirilen 40 maddeden oluşan ve 5'li likert tipi "Grasha-Riechmann Öğretme Stilleri Ölçeği" kullanılmıştr. Ölçeğin güvenirliğine ilişkin Grasha'nın (1996) ulaştı̆ı değerler, Türkçe formunda Üredi tarafindan ulaşılan değerler ve araştırma kapsamında ulaşılan değerler Tablo 2'de verilmiştir.

Tablo 2. Grasha- Riechmann öğretme stili ölçeğine ilişsin cronbach alfa değerleri

\begin{tabular}{lccc}
\hline Alt ölçekler & Orjinal & Üredi & Araşttrma değerleri \\
\hline Uzman &, 75 &, 75 &, 75 \\
Otoriter &, 80 &, 76 &, 78 \\
Kişisel Model &, 66 &, 83 &, 81 \\
Rehber &, 84 &, 87 &, 89 \\
Danışman &, 70 &, 77 &, 75 \\
Toplam &, 85 &, 90 &, 90 \\
\hline
\end{tabular}

Tablo 2'deki veriler incelendiğinde Grasha'nın hazırlamış olduğu ölçeğin Cronbach Alfa katsayısı toplamda .85 'tir. Üredi tarafindan Türkçe'ye uyarlanan ölçeğin Cronbach Alfa katsayısı .89'dur. Araştırma kapsamında ulaşılan Cronbach Alfa katsayısı $.90^{\prime}$ dur.

\section{Verilerin Analizi}

Çalışma sonucunda Grasha- Riechmann öğretme stili ölçeğinden elde edilen veriler "http://longleaf.net/teachingstyle.html" adresindeki programa girilmiş ve beş öğretme stilini içeren puanlar "düşük", "orta" ve "yüksek" olmak üzere üç farklı düzeyde hesaplanmıştr. Bu doğrultuda beş öğretme stiline ait sonuçlardan en yüksek puana sahip olanlar dikkate alınarak öğretmenlerin tercih etmiş oldukları öğretme stilleri belirlenmiştir.

Araştırma kapsamında Grasha- Riechmann Öğretme Stili Ölçeği alt boyutlarına yönelik toplanan verilerin normal dağılımıyla ilgili betimsel istatistikleri incelendiğinde, Kolmogorov-Smirnov p anlamlılık değeri 0,05 değerinden küçük olduğu için verilerin analizinde non-parametrik analizler yapılmıştı. Araştırmada nicel veriler IBM SPSS (Statistical Package for Social Sciences) 22.0 paket programı kullanılarak analiz edilmiştir.

\section{Bulgular}

$\mathrm{Bu}$ bölümde araştırma verilerinden elde edilen istatistiksel çözümleme sonucundaki bulgulara yer verilmiştir.

\subsection{Sosyal Bilgiler Öğretmenlerin Öğretme Stillerine Yönelik Bulgular}

Araştırmanın birinci alt problemi ile Sosyal bilgiler öğretmenlerin Grasha-Riechmann Öğretme Stili Ölçeğine göre alt boyutları belirlenmeye çalışılmıştır. Analiz sonucunda Muğla ilindeki sosyal bilgiler öğretmenlerinin tercih ettikleri öğretme stillerine yönelik frekans dağılımı Tablo 3'te sunulmuştur. 
Tablo 3. Sosyal bilgiler öğretmenlerinin öğretme stillerine göre dağılımı

\begin{tabular}{lcccc}
\hline Öğretme Stili Alt Boyutları & N & $\%$ & $\bar{X}$ & Ss. \\
\hline Uzman & 57 & 34,5 & 4,00 & 0,42 \\
Otoriter & 7 & 4,2 & 3,61 & 0,51 \\
Kişisel model & 15 & 9,1 & 3,92 & 0,32 \\
Rehber & 80 & 48,5 & 4,15 & 0,45 \\
Danışman & 6 & 3,6 & 3,77 & 0,44 \\
\hline
\end{tabular}

Tablo 3'teki verileri incelediğimizde öğretme stilleri alt boyut ortalamalarının birbirine yakın değerler aldığı görülmektedir. Bu doğrultuda rehber öğretme stili ortalamasının en yüksek $(\bar{X}=4,15)$ ortalamaya sahip olduğu ve öğretmenlerinin en çok $(\mathrm{N}=80)$ rehber öğretme stilini tercih ettiği anlaşılmaktadır. Bu stili tercih eden öğretmenler öğrenci merkezli öğrenmeleri desteklemek için çaba gösterirler. Buna göre yapılandırmacı anlayışa uygun öğrenci merkezli yaklaşım daha çok tercih edilmiştir. Öğretmenler arasında baskın olan diğer bir öğretme stili de uzman ( $N=57)$ alt boyutu olduğu görülmektedir. Çalışma grubundaki öğretmenlerin en az tercih ettikleri öğretme stili ise danışman $(\mathrm{N}=6)$ olmuştur. Sonuç olarak öğretme stilleriyle ilgili analizlere bakıldığında öğretmenlerin sırasıyla, rehber, uzman, kişisel model, otoriter ve danışman öğretme stillerini tercih ettiği görülmüştür.

\subsection{Sosyal Bilgiler Öğretmenlerinin Demografik Değişkenleri ille Öğretme Stillerine Yönelik Bulgular}

Araştırmanın ikinci alt probleminde yer alan her bir değişkene ilişkin anlamlı farklılığı belirlemek için non-parametrik analizler uygulanmıştır.

Tablo 4. Öğretmenlerin cinsiyetleri ile Grasha-Riechmann öğretme stili ölçeği alt boyutlarına ilişkin Mann Whitney $\mathrm{U}$ testi analiz sonuçları

\begin{tabular}{|c|c|c|c|c|c|c|}
\hline Öğretme Stilleri & Cinsiyet & $\mathrm{N}$ & Sira Ort. & Sıra Toplamı & $u$ & $p$ \\
\hline \multirow{2}{*}{ Uzman } & Kadın & 88 & 77,82 & 6848,00 & \multirow{2}{*}{2932,00} & \multirow{2}{*}{0,13} \\
\hline & Erkek & 77 & 88,92 & 6847,00 & & \\
\hline \multirow{2}{*}{ Otoriter } & Kadın & 88 & 81,13 & 7139,00 & \multirow{2}{*}{3223,00} & \multirow{2}{*}{0,58} \\
\hline & Erkek & 77 & 85,14 & 6556,00 & & \\
\hline \multirow{2}{*}{ Kişisel Model } & Kadın & 88 & 85,18 & 7495,50 & \multirow{2}{*}{3196,50} & \multirow{2}{*}{0,52} \\
\hline & Erkek & 77 & 80,51 & 6199,50 & & \\
\hline \multirow{2}{*}{ Rehber } & Kadın & 8 & 82,50 & 7260,00 & \multirow{2}{*}{3344,00} & \multirow{2}{*}{0,88} \\
\hline & Erkek & 77 & 83,57 & 6435,00 & & \\
\hline \multirow{2}{*}{ Danışman } & Kadın & 88 & 85,81 & 7551,50 & \multirow{2}{*}{3140,50} & \multirow{2}{*}{0,41} \\
\hline & Erkek & 77 & 79,79 & 6143,50 & & \\
\hline
\end{tabular}

Tablo 4'e göre öğretmenlerin tercih etmiş oldukları uzman $(U=2932,000 ; p>05)$, otoriter $(U=3223,000 ; p>, 05)$, kişisel model $(U=3196,500 ; p>, 05)$, rehber $(U=3344,000 ; p>, 05)$ ve danışman $(U=3140,500 ; p>, 05)$ öğretme stilleri ile cinsiyet değişkeni arasında anlamlı bir farklılık olmadığı bulunmuştur.

Tablo 5. Öğretmenlerin mesleki kıdem değişkeni ile Grasha Riechmann öğretme stili ölçeği alt boyutlarına ilişkin Kruskal-Wallis testi analiz sonuçları

\begin{tabular}{llccccc}
\hline Öğretme Stilleri & Mesleki Kıdem & N & Sıra Ort. & Sd & $X^{2}$ & $p$ \\
\hline \multirow{4}{*}{ Uzman } & $1-5$ yıl & 15 & 70,93 & & & \\
& $6-10$ yıl & 42 & 77,02 & & & \\
& $11-15$ yıl & 52 & 99,51 & 4 & 13,44 & 0,00 \\
& $16-20$ yıl & 32 & 86,47 & & & \\
& 21 ve üstü & 24 & 60,60 & & & \\
& $1-5$ yıl & 15 & 77,07 & & & \\
Otoriter & $6-10$ yıl & 42 & 75,88 & & & \\
& $11-15$ yıl & 52 & 90,49 & & & \\
& $16-20$ yıl & 32 & 83,92 & 4 & 2,497 & 0,64 \\
& 21 ve üstü & 24 & 81,71 & & &
\end{tabular}

|Kastamonu Eğitim Dergisi, 27(2), 2019| 


\begin{tabular}{lllcccc}
\hline Öğretme Stilleri & Mesleki Kıdem & N & Sıra Ort. & Sd & $X^{2}$ & $p$ \\
\hline \multirow{4}{*}{ Kişisel Model } & $1-5$ yıl & 15 & 101,73 & & & \\
& $6-10$ yıl & 42 & 76,55 & & & \\
& $11-15$ yıl & 52 & 80,79 & 4 & 7,663 & 0,10 \\
& $16-20$ yıl & 32 & 73,47 & & & \\
& 21 ve üstü & 24 & 100,08 & & & \\
& $1-5$ yıl & 15 & 64,30 & & & \\
Rehber & $6-10$ yıl & 42 & 93,48 & & & \\
& $11-15$ yıl & 52 & 88,00 & & & \\
& $16-20$ yıl & 32 & 69,86 & 4 & 7,410 & 0,11 \\
& 21 ve üstü & 24 & 83,04 & & & \\
& $1-5$ yıl & 15 & 75,67 & & & \\
Danışman & $6-10$ yıl & 42 & 80,69 & & & \\
& $11-15$ yıl & 52 & 99,34 & & & \\
& $16-20$ yıl & 32 & 74,08 & 4 & 10,06 & 0,03 \\
& 21 ve üstü & 24 & 68,13 & & & \\
\hline
\end{tabular}

Tablo 5'te öğretmenlerin mesleki kıdemi açısından sadece uzman $(\chi 2(4)=13,448, p<.05)$ ve danışman öğretme stillerinde $(\chi 2(4)=10,062, p<.05)$ anlamlı bir farklııık bulunmuştur. Anlamlı farklıı̆ı̆ hangi mesleki kıdem düzeyinde olduğunu tespit etmek için ikili karşılaştırmalarda kullanılan Mann Whitney-U testi uygulanmıştır. Buna göre mesleki kıdem yılı 11-15 yıl arasında olan öğretmenlerin uzman öğretme stilleri sıralama puanı, mesleki kıdem yılı 1-5 yıl, 6-10 yıl, 21 ve üstü olan öğretmenlere göre daha baskın çıkmıştr. Ayrıca mesleki kıdem yılı 11-15 yıl arasında olan öğretmenlerin danışman öğretme stilleri, mesleki kıdem yılı 6-10 yıl, 16-20 yıl, 21 ve üstü olan öğretmenlere göre daha baskın çıkmıştır.

Tablo 6. Sınıf mevcudu değişkeni ile Grasha-Riechmann öğretme stili ölçeği alt boyutlarına ilişkin Kruskal Wallis testi analizi

\begin{tabular}{|c|c|c|c|c|c|c|}
\hline Öğretme Stilleri & Sınıf Mevcudu & $\mathrm{N}$ & Sıra Ort. & Sd & $x^{2}$ & $\mathrm{p}$ \\
\hline \multirow{4}{*}{ Uzman } & 5-15 arası & 25 & 75,22 & \multirow{4}{*}{3} & \multirow{4}{*}{18,723} & \multirow{4}{*}{0,00} \\
\hline & $16-25$ arası & 84 & 70,77 & & & \\
\hline & $26-35$ arası & 45 & 107,32 & & & \\
\hline & 36 ve üstü & 11 & 94,55 & & & \\
\hline \multirow{4}{*}{ Otoriter } & 5-15 arası & 25 & 84,76 & \multirow{4}{*}{3} & \multirow{4}{*}{9,907} & \multirow{4}{*}{0,01} \\
\hline & $16-25$ arası & 84 & 72,76 & & & \\
\hline & 26-35 arası & 45 & 100,22 & & & \\
\hline & 36 ve üstü & 11 & 86,73 & & & \\
\hline \multirow{4}{*}{ Kişisel Model } & 5-15 arası & 25 & 78,90 & \multirow{4}{*}{3} & \multirow{4}{*}{1,810} & \multirow{4}{*}{0,613} \\
\hline & $16-25$ arası & 84 & 87,32 & & & \\
\hline & $26-35$ arası & 45 & 80,30 & & & \\
\hline & 36 ve üstü & 11 & 70,41 & & & \\
\hline \multirow{4}{*}{ Rehber } & 5-15 arası & 25 & 96,02 & \multirow{4}{*}{3} & \multirow{4}{*}{3,450} & \multirow{4}{*}{0,327} \\
\hline & $16-25$ arası & 84 & 84,17 & & & \\
\hline & 26-35 arası & 45 & 76,37 & & & \\
\hline & 36 ve üstü & 11 & 71,59 & & & \\
\hline \multirow{4}{*}{ Danışman } & 5-15 arası & 25 & 101,38 & \multirow{4}{*}{3} & \multirow{4}{*}{10,613} & \multirow{4}{*}{0,01} \\
\hline & $16-25$ arası & 84 & 78,70 & & & \\
\hline & 26-35 arası & 45 & 89,02 & & & \\
\hline & 36 ve üstü & 11 & 49,45 & & & \\
\hline
\end{tabular}

Tablo 6'da öğretmenlerin sınıf mevcudu değişkenine göre sadece uzman $(\chi 2(3)=18,723, p<.05)$, otoriter $(\chi 2(3)=$ $9,907, p<.05)$ ve danışman öğretme stilleri $(\chi 2(3)=10,613, p<.05)$ arasında anlamlı bir farklıık bulunmuştur. Anlamlı farklılığın tespit etmek için ikili karşılaştırmalarda kullanılan Mann Whitney-U testi uygulanmıştr. Analizi sonucunda sınıf mevcudu 26-35 olan öğretmenlerin uzman öğretme stilleri, sınıf mevcudu 5-15 olan öğretmenlere göre daha baskın çıkmıştır (U=319,000; $p<.05)$. Sınıf mevcudu 26-35 olan öğretmenlerin otoriter öğretme stilleri, sınıf mevcudu 16-25 olan öğretmenlere göre daha baskın çıkmıştı $(U=1255,000 ; p<.05)$. Sınıf mevcudu 5-15 arasında olan öğretmenlerin danışman öğretme stili, sınıf mevcudu 16-25 ve 36 ve üstü olan öğretmenlere göre daha yüksek çıkmıştır. 
Tablo 7. Hizmet içi eğitim değişkeni ile Grasha-Riechmann öğretme stili ölçeği alt boyutlarına ilişkin Mann Whitney-U testi analiz sonuçları

\begin{tabular}{|c|c|c|c|c|c|c|}
\hline Öğretme Stilleri & Hizmet İçi Eğitim Durumu & $\mathrm{N}$ & Sıra Ort. & Sıra Toplamı & $U$ & $p$ \\
\hline \multirow{2}{*}{ Uzman } & Katıldım & 125 & 84,2 & 10530, & \multirow{2}{*}{234,5} & \multirow{2}{*}{0,55} \\
\hline & Katılmadım & 40 & 79,1 & 3164,5 & & \\
\hline \multirow{2}{*}{ Otoriter } & Katıldım & 125 & 84,1 & 10520, & \multirow{2}{*}{235,5} & \multirow{2}{*}{0,57} \\
\hline & Katılmadım & 40 & 79,3 & 3174,5 & & \\
\hline \multirow{2}{*}{ Kişisel Model } & Katıldım & 125 & 99,6 & 9708,0 & \multirow{2}{*}{183,0} & \multirow{2}{*}{0,01} \\
\hline & Katılmadım & 40 & 77,6 & 3987,0 & & \\
\hline \multirow{2}{*}{ Rehber } & Katildım & 125 & 86,1 & 10764, & \multirow{2}{*}{211,5} & \multirow{2}{*}{0,13} \\
\hline & Katılmadım & 40 & 73,2 & 2930,5 & & \\
\hline \multirow{2}{*}{ Danışman } & Katıldım & 125 & 84,6 & 10586, & \multirow{2}{*}{228,0} & \multirow{2}{*}{0,42} \\
\hline & Katılmadım & 40 & 77,7 & 3109,0 & & \\
\hline
\end{tabular}

Tablo 7'de sadece kişisel model öğretme stili ile hizmet içi eğitim değişkeni arasında anlamlı bir farklılık olduğu bulunmuştur (U=1833,000; $p<, 05)$. Bu sonuçlara göre hizmet içi eğitime katılan öğretmenlerin kişisel model öğretme stili, hizmet içi eğitime katılmayan öğretmenlere göre daha baskın çıkmıştır.

Tablo 8. Sosyal bilgiler dersliği değişkeni ile Grasha-Riechmann öğretme stili ölçeği alt boyutlarına ilişkin Mann Whitney $U$ testi analiz sonuçları

\begin{tabular}{|c|c|c|c|c|c|c|}
\hline Öğretme Stilleri & Derslik & $\mathrm{N}$ & Sira Ort. & Sıra Toplamı & $U$ & $p$ \\
\hline \multirow{2}{*}{ Uzman } & Var & 47 & 77,76 & 3654,50 & \multirow{2}{*}{2526,500} & \multirow{2}{*}{0,37} \\
\hline & Yok & 118 & 85,09 & 10040,50 & & \\
\hline \multirow{2}{*}{ Otoriter } & Var & 47 & 75,03 & 3526,50 & \multirow{2}{*}{2398,500} & \multirow{2}{*}{0,17} \\
\hline & Yok & 118 & 86,17 & 10168,50 & & \\
\hline \multirow{2}{*}{ Kişisel Model } & Var & 47 & 82,50 & 3877,50 & \multirow{2}{*}{2749,500} & \multirow{2}{*}{0,93} \\
\hline & Yok & 118 & 83,20 & 9817,50 & & \\
\hline \multirow{2}{*}{ Rehber } & Var & 47 & 82,88 & 3895,50 & \multirow{2}{*}{2767,500} & \multirow{2}{*}{0,98} \\
\hline & Yok & 118 & 83,05 & 9799,50 & & \\
\hline \multirow{2}{*}{ Danışman } & Var & 47 & 79,66 & 3744,00 & \multirow{2}{*}{2616,000} & \multirow{2}{*}{0,56} \\
\hline & Yok & 118 & 8433 & 995100 & & \\
\hline
\end{tabular}

Tablo 8'e göre öğretmenlerin tercih etmiş oldukları uzman $(U=2526,500 ; p>, 05)$, otoriter $(U=2398,500 ; p>, 05)$, kişisel model $(U=2749,500 ; p>, 05)$, rehber $(U=2767,500 ; p>, 05)$ ve danışman $(U=2616,000 ; p>, 05)$ öğretme stilleri ile sosyal bilgiler dersliği değişkeni arasında anlamlı bir farklılık olmadığı bulunmuştur.

Tablo 9. Sınıf düzeyi değişkeni ile Grasha-Riechmann öğretme stili ölçeği alt boyutlarına ilişkin Kruskal-Wallis testi analiz sonuçları

\begin{tabular}{|c|c|c|c|c|c|c|}
\hline Öğretme Stilleri & Sınıf Düzeyi & $\mathrm{N}$ & Sira Ort. & Sd & $x^{2}$ & $\mathrm{p}$ \\
\hline \multirow{3}{*}{ Uzman } & $5 . \sin I f$ & 38 & 72,63 & \multirow{3}{*}{2} & \multirow{3}{*}{2,563} & \multirow{3}{*}{0,27} \\
\hline & $6 . \sin I f$ & 50 & 88,47 & & & \\
\hline & 7.sınıf & 77 & 84,56 & & & \\
\hline \multirow{3}{*}{ Otoriter } & 5.sınıf & 38 & 79,42 & \multirow{3}{*}{2} & \multirow{3}{*}{0,281} & \multirow{3}{*}{0,86} \\
\hline & $6 . \sin ı f$ & 50 & 83,88 & & & \\
\hline & 7.sınıf & 77 & 84,19 & & & \\
\hline \multirow{3}{*}{ Kişisel Model } & $5 . \sin ı f$ & 38 & 63,80 & \multirow{3}{*}{2} & \multirow{3}{*}{9,053} & \multirow{3}{*}{0,01} \\
\hline & $6 . \sin ı f$ & 50 & 83,70 & & & \\
\hline & 7.sınıf & 77 & 92,02 & & & \\
\hline \multirow{3}{*}{ Rehber } & 5.sınıf & 38 & 69,89 & \multirow{3}{*}{2} & \multirow{3}{*}{4,888} & \multirow{3}{*}{0,08} \\
\hline & $6 . \sin ı f$ & 50 & 81,39 & & & \\
\hline & 7.sınıf & 77 & 90,51 & & & \\
\hline \multirow{3}{*}{ Danışman } & $5 . \sin ı f$ & 38 & 76,79 & \multirow{3}{*}{2} & \multirow{3}{*}{1,428} & \multirow{3}{*}{0,49} \\
\hline & $6 . \sin I f$ & 50 & 88,87 & & & \\
\hline & 7.sınıf & 77 & 82,25 & & & \\
\hline
\end{tabular}


Tablo 9'da sadece kişisel model öğretme stili $(\chi 2(2)=18,723, p<.05)$ alt boyutunda sınıf mevcudu değişkenine göre anlamlı bir farklılık bulunmuştur. Mann Whitney-U testi analizi sonucunda, sınıf düzeyi 6. olan öğretmenlerin kişisel öğretme sıralama puanı, sınıf düzeyi 5. sınıf olan öğretmenlere göre daha baskın çıkmıştır. Benzer şekilde sınıf düzeyi 7. olan öğretmenlerin kişisel model öğretme stili sıralama puanı, sınıf düzeyi 5. sınıf olan öğretmenlere göre daha baskın çıkmıştır (U=965,500; $p<.05)$.

\section{Tartışma ve Sonuç}

Bu araştırma, sosyal bilgiler öğretmenlerinin öğretme stillerini belirleyebilmek ve tercih edilen stiller ile çeşitli değişkenler arsındaki ilişkileri incelemek amacıyla yapılmıştr. Buna göre araştrmanın birinci alt probleminde öğretmenlerin öğretme stillerine ilişkin verilerin analizi sonucunda; araştırmaya katılan sosyal bilgiler öğretmenlerinin yarıya yakını $(\% 48,5)$ rehber öğretme stilini tercih ettiği görülmüştür. Bu öğretme stilinin yüksek düzeyde olması öğretmenlerin sınıf ortamında işbirlikçi ve öğrenci merkezli bir sınıf ortamı oluşturduğunu göstermektedir. Öğretme stillerine yönelik farkıı çalışmalara baktığımızda çeşitli branşlardaki öğretmenlerin rehber öğretme stilini tercih ettikleri görülmüştür (Grasha, 2002; Bilgin ve Bahar, 2008; Altay, 2009; Mertoğlu, 2011; Maden, 2012; Süral, 2013; Dilekli, 2015; Kabaran, 2016). Buna göre elde edilen bulgular diğer çalışmalarla benzerlik göstermektedir. Öğretmenler ikinci sırada öğretmen merkezli anlayış olan uzman öğretme stilini tercih etmişlerdir. Bu sonuç, eğitim anlayışımızdaki öğretmen merkezli süreçten öğrenci merkezli sürece geçişin sonucu olarak yorumlanmıştr. Ulaşılan bu sonuç Muğla il ve ilçelerinde görevli sosyal bilgiler öğretmenleri arasında geleneksel ve çağdaş eğitimdeki iki anlayışın birlikte devam ettiğini göstermektedir. Süral (2013) ilköğretim öğretmenlerine yönelik çalışmasında benzer bir bulguya ulaşmıştr. Sonuç olarak öğretme stilleriyle ilgili analizlere bakıldığında öğretmenlerin sırasıyla rehber, uzman, kişisel model, otoriter ve danışman öğretme stillerini tercih ettikleri ve davranışçı bir yaklaşımdan yapılandırmacı bir anlayışa geçişin göstergesi olarak rehber ve uzman öğretme stillerinde yoğunlaştkları görülmüştür.

Araştırmanın ikinci alt problemine göre kadın ve erkek öğretmenlerin öğretme stilleri sıralama puanları açısından bir farklılık olmadığı görülmüştür. Bu sonuca göre kadın ve erkek öğretmenlerin öğretme stili tercihleri açısından anlamlı bir farklılık göstermediği anlaşılmıştır. Öğretme stillerine yönelik yapılan diğer çalışmalara baktığımız da; Altay (2009), Babadoğan, Kassenova ve Karaşahinoğlu (2014), Kabaran (2016), Kılıç ve Dilbaz (2013), Maden (2012) ve Üredi (2006) cinsiyete göre öğretme stillerinin farklılaşmadığını tespit edilmiş olup, araştırma sonucu ile benzerlik göstermektedir. Araştırma bulgularından farklı olarak Saracaloğlu, Dinçer, Dedebali ve Dursun (2011) farklı branşlardaki öğretmenlere yönelik yaptıkları çalışmada sadece rehber öğretme stili ile cinsiyet arasında anlamlı bir farklılık bulmuştur. Araştırmanın bir diğer değişkeni olan mesleki kıdeme göre sadece uzman ve danışman öğretme stillerinde anlamlı bir farklıık bulunmuştur. Bu sonuca göre 11-15 yıl arasında mesleki deneyimi olan öğretmenlerin uzman öğretme stili, diğer mesleki kıdemlere göre baskın çıkmıştr. Buna göre 11-15 yıl arasında mesleki deneyimi olan öğretmenler alanda kendilerini yeterli bilgi ve uzmanlı̆̆a sahip olarak görmektedirler. Araştırmada sınıf mevcuduna göre uzman, otoriter ve danışman öğretme stilleri arasında anlamlı bir farklıık bulunmuştur. Sınıf mevcudu 26-35 arası olan öğretmenlerin uzman öğretme stilleri sıralama puanı sınıf mevcudu 5-15 ve 16-25 olan öğretmenlere göre daha baskın çıkmıştır. Yani sınıf mevcudu arttkça öğretmen merkezli stillere yönelik tercihler artmaktadır. Buna göre sınıf mevcudu öğretme sürecinde etkili ve belirleyici olabilmektedir. Bu sonuçtan farklı olarak; Üredi (2011) sınıf mevcuduna göre öğretme stilleri arasında anlamlı bir fark bulmamıştır. Araştırmada hizmet içi eğitim durumu açısından sadece kişisel model öğretme stilinde anlamlı bir farklılık bulunmuştur. Bu sonuç hizmet içi eğitime katılan öğretmenlerin kişisel model öğretme stilini tercih etmesi, hizmet içi eğitime katılmayan öğretmenlere göre daha baskın çıkmıştır. Kişisel model öğretme stilinde öğretmen öğrencilere rol model olarak öğrenmelerini desteklemektedir. Bu doğrultuda hizmet içi eğitim alan sosyal bilgiler öğretmenleri eğitim durumlarında kişisel model stili daha çok tercih etmektedirler. Saracaloğlu, Karademir, Dinçer ve Dedebali'nin (2017) ulaştı̆̆ bilgilere göre sadece danışman öğretme stilinde hizmet içi eğitim alan öğretmenler lehine anlamlı farklıık bulunmuştur. Sosyal bilgiler dersliğine göre veriler analiz edildiğinde öğretme stilleri arasında anlamlı bir farklılık olmadığı anlaşılmıştır. Araştırmada sınıf düzeyine göre veriler analiz edildiğinde sadece kişisel model öğretme stili arasında anlamlı bir farklıık bulunmuştur. Bu sonuca göre sosyal bilgiler öğretmenlerinin sınıf düzeyi yükseldikçe kişisel model stili tercih etme düzeyi de artmaktadır.

Araştırmanın genel bir sonucuna göre Muğla il ve illçelerinde görevli sosyal bilgiler öğretmenlerinin yapılandırmacı yaklaşımı temsilen rehber, davranışçı yaklaşımı temsilen de uzman öğretme stillerini daha çok tercih ettikleri görülmüştür. Bu durum eğitim-öğretim programlarında yaşanan felsefi anlayışın değişimi olarak görülmektedir. Ayrıca öğretmenlerin mesleki kıdemleri, sınıf düzeyi ve sınıf mevcudu öğretme stillerine yansımakta ve kıdemi, sınıf düzeyi ve sınıf mevcudu yükseldikçe öğretmen merkezli (uzman ) stile olan tercih artmaktadır. 


\section{5. Öneriler}

Araştrrma sonuçlarından hareketle şu önerilerde bulunulabilir:

- Muğla il ve ilçelerindeki sosyal bilgiler öğretmenlerinin tercih etmiş oldukları öğretme stilleri ile ilgili hizmet içi eğitim verilerek davranış̧ı ve yapılandırmacı yaklaşımları daha net görmeleri sağlanabilir.

- Araştırma sonuçlarına göre bazı öğretme stilleri ile değişkenler arasında anlamlı bir farklıık bulunmuştur. Farklı değişkenler ile öğretme stilleri arasında daha geniş kapsamlı bir araştırma ya da daha derinlemesine nitel bir araştırma yürütülebilir.

\section{Kaynakça}

Aktan, S. (2012). Öğrencilerin akademik başarısı, öz düzenleme becerisi, motivasyonu ve öğretmenlerin öğretim stilleri arasındaki iliş̧ki. Yayımlanmamış Doktora Tezi. Balıkesir: Balıkesir Üniversitesi, Sosyal Bilimler Enstitüsü.

Altay, S. (2009). Beşinci sınıf öğretmenlerinin sosyal bilgiler dersindeki öğretme stillerinin incelenmesi. Yayımlanmamış Yüksek Lisans Tezi. Adana: Çukurova Üniversitesi, Sosyal Bilimler Enstitüsü.

Artvinli, E. (2010). Coğrafya öğretmenlerinin öğretme stilleri. Elektronik Sosyal Bilimler Dergisi, 9(33), 387-408.

Babadoğan, C., Kassenova, S., ve Karaşahinoğlu, A. (2014). Öğretmenlerin öğrenme ve öğretme stillerinin bazı değişkenler açısından incelenmesi. Eğitim Bilimleri ve Uygulama, 13(26), 125-146.

Bilgin, ì., ve Bahar, M. (2008). Sınıf öğretmenlerinin öğretme ve öğrenme stilleri arasındaki ilişkinin incelenmesi. Gazi Üniversitesi Gazi Eğitim Fakültesi Dergisi, 28(1).

Coldren, J. ve Hively, J. (2009). Interpersonal teachıng style and student Impression formation. College Teachıng, 57(2), 93-98.

Corcoran, V. M. (1997). Teaching styles being utilized in the higher education of nutrition practitioners. Doctoral Dissertational, Temple University Graduate Board, USA, UMI Number: 9724223.

Yüksel, İ. (2013). Öğretimsel stil tercihlerinin öz-düzenleme beceri düzeylerini yordama gücü. Dicle Üniversitesi Ziya Gökalp Eğitim Fakültesi Dergisi, 20, 212-229.

Çolak, E. ve Şensoy, Ö. (2010). Öğretmenlerin öğretme stili boyutlarının bazı değişkenler açısından incelenmesi. I.Ulusal Eğitim Programları ve Öğretim Kongresi, Balıkesir: Balıkesir Necatibey Üniversitesi.

Deveci, E. (2008). Öğretim stillerinin farklı zekâ türlerine sahip 6. sınıf öğrencilerinin fen ve teknoloji ders başarısı ile ilişkisi. Yayımlanmamış Yüksek Lisans Tezi. Bolu: Abant İzzet Baysal Üniversitesi, Eğitim Bilimler Enstitüsü.

Demir, B. (2015). Müzik öğretmenlerinin öğretim stili tercihlerinin belirli değişkenlere göre incelenmesi. Yayımlanmamış Yüksek Lisans Tezi. Niğde: Niğde Üniversitesi, Eğitim Bilimleri Enstitüsü.

Dilekli, Y. (2015). Öğretmenlerin düşünmeyi öğretmeye yönelik yaptıları sınıf içi uygu-lamaları, özyeterlik düzeyleri ve öğretim stilleri arasındaki ilişki. Yayımlanmamış Doktora Tezi. Balıkesir: Balıkesir Üniversitesi, Sosyal Bilimler Enstitüsü.

Doğanay, A. (2003). Öğretimde kavram ve genellemelerin geliştirilmesi. Öztürk, C., ve Dilek, D. (Ed.), Hayat bilgisi ve sosyal bilgiler öğretimi, Ankara: Pegem Yayıncllık.

Erden, M. (1996). Sosyal bilgiler öğretimi. İstanbul: Alkım Kitapevi.

Erdoğdu, E. (2010). Sosyal bilgiler öğretmenlerinin kullandıkları yöntem/teknikler ve karşılaştıkları kullanım güçlükleri. Yayımlanmamış Yüksek Lisans Tezi. Kütahya: Dumlupınar Üniversitesi, Sosyal Bilimler Enstitüsü.

Gencel, i. E. (2013). Öğretmenlerin öğretim stilleri tercihleri: Türkiye-ABD karşılaştrılıması. Turkish Studies, 8(8), 635-648.

Gülten, D. ve Özkan, E. (2014). illköğretim öğretmenlerinin öğretim stillerinin çeşitli değişkenler açısından incelenmesi. Dicle Üniversitesi Ziya Gökalp Eğitim Fakültesi Dergisi, 23, 193-218.

Grasha, A. F. (1994a). A special section discovering your best teaching styles. College Teaching, 42(4), 122-124.

Grasha, A. F. (1994b). A matter of style: the teacher as expert, formal authority, personel model, facilitator and delegator. College Teaching, 42(4), 12-20,

Grasha, A. F. (1996). Teaching with style: a practical guide to enhancing learning by understanding teaching and learning styles. San Bernardino: Alliance Publishers.

Grasha, A. F., ve Yangarber-Hicks, N. (2000). Integrating teaching styles and learning styles with instructional technology. College Teaching, 48(1), 2-10.

Grasha, A. (2002). The dynamics of one-on-one teaching. College Teaching, 50(4), 139-146.

Grasha, A. F. (2002). Teaching with style. San Bernadino: Alliance Publishers.

Gregorc, A. F. (1979). Learning/teaching styles: potent forces behind them, Educational Leadership, 36(4), 234-236.

Kabaran, H. (2016). Öğretim elemanlarının teknolojik pedagojik alan bilgileri (TPAB) ile öğretme stilleri arasındaki ilişkinin incelenmesi. Yayımlanmamış Yüksek Lisans Tezi. Muğla: Muğla Sıtkı Koçman Üniversitesi, Eğitim Bilimleri Enstitüsü. 
Kaleci, F. (2012). Matematik öğretmen adaylarının epistemolojik inançları ile öğrenme ve öğretim stilleri arasındaki ilişki. Yayımlanmamış Yüksek Lisans Tezi. Konya: Necmettin Erbakan Üniversitesi, Eğitim Bilimleri Enstitüsü.

Karataş, E. (2014). Sosyal bilgiler öğretiminde öğrenme ve öğretim stillerinin karşılaştırmalı analizi. Yayımlanmamış Yüksek Lisans Tezi. Ankara: Gazi Üniversitesi, Eğitim Bilimleri Enstitüsü.

Karasar, Niyazi (1999). Bilimsel araştırma yöntemi. Ankara: Nobel Yayıncılık.

Kaya, E. ve Ekici, M. (2017). Sosyal bilgiler öğretmenlerinin epistemolojik inançları ve öğretim stillerinin çeşitli değişkenler açısından incelenmesi. İlköğretim Online, 16(2), 782-813. Erişim adresi http://dergipark.ulakbim.gov.tr/ilkonline/article/view/5000183703

Kılıç, F., ve Dilbaz, A. G. (2013). Fen lisesi öğretmenlerinin öğretim stillerinin çeşitli değiş-kenler açısından incelenmesi. The Journal of Academic Social Science Studies, 6(6), 715-738.

Kulinna, P. H. ve Cothran, D. J. (2003). Physical education teacher's self-reported use and perceptions of various teaching styles. Learning and Instruction, 13(6), 597-609.

Kolay, B. (2008). Öğretim stillerinin farklı öğrenme stillerine sahip 6. sınıf öğrencilerinin fen ve teknoloji ders başarısına etkisi. Yayımlanmamış Yüksek Lisans Tezi. Bolu: Abant İzzet Baysal Üniversitesi, Sosyal Bilimler Enstitüsü.

Maden, S. (2012). Türkçe öğretmenlerinin öğretme stilleri. Uluslararası Türkçe Edebiyat Kültür Eğitim Dergisi, 1, 178-200.

McGowan, S. R. (2008). Teaching styles of technical college core and occupational faculty: their relationship to student achievement. Doctoral Dissertation. Capella University, United States, UMI Number: 3296731.

Mertoğlu, H. (2011). Fen ve teknoloji öğretmenlerinin öğretim stillerinin ve yapılandırmacı öğrenme ortamına ilişkin algılarının öğretim uygulamalarına etkileri. Yayımlanmamış Doktora Tezi. İstanbul: Marmara Üniversitesi, Eğitim Bilimleri Enstitüsi.

Mutluoğlu, A. (2012). ilköğretim matematik öğretmenlerinin öğretim stili tercihlerine göre teknolojik pedagojik alan bilgilerinin incelenmesi. Yayımlanmamış Yüksek Lisans Tezi. Konya: Necmettin Erbakan Üniversitesi, Eğitim Bilimleri Enstitüsü.

Piaget, J. (1993). Eğitim Nereye Gidiyor? Anlamak Keşfetmektir. (Çev. Aslan, K. ve Dönmezer) İzmir: Ege Üniversitesi Basımevi.

Üredi, L. (2006). ilköğretim ı. ve II. kademe öğretmenlerinin öğretim stili tercihlerine göre öğretmenlik mesleğine ilişkin algılarının incelenmesi. Yayımlanmamış Doktora Tezi. İstanbul: Marmara Üniversitesi, Eğitim Bilimleri Enstitüsi.

Üredi, L.,ve Üredi, I. (2007). Sınıf öğretmenlerinin tercih ettikleri öğretim stillerinin yordayıcısı olarak öğretmenlik mesleğine ilişkin algıları. Mersin Üniversitesi Eğitim Fakültesi Dergisi, 3(2), 133-144.

Sarı, M. H. ve Aksoy, N. C. (2016). Sınıf öğretmenlerinin matematik öğretimi kaygısı ile öğretme stilleri tercihleri arasındaki ilişki. Turkish Studies, 11(3), 1953-1968

Süral, S. (2010). Pamukkale Üniversitesi'nin farklı fakültelerinde görev yapan öğretim ele-manlarının öğretme stillerini karşılaştırılmaSI. E-Journal of New World Sciences Academy, 5(3), 1227-1242.

Süral, S. (2013). Ilköğretimde görev yapan öğretmenlerin öğretme stillerinin sınıf yönetimi yaklaşımları ve öğretmenlik mesleğine yönelik tutumları arasındaki ilişki. Yayımlanmamış Doktora Tezi. Aydın: Adnan Menderes Üniversitesi, Eğitim Bilimleri Enstitüsü.

Şahin, E. (2010). IIlköğretim sınıf öğretmenlerinin öğretim stili tercihlerinin, cinsiyetlerinin, mesleki kıdemlerinin, özyeterlik algılarının ve özyönetimli öğrenmeye hazırbulunuşluk düzeylerinin mesleki yeterlikleri üzerindeki etkisi. Yayımlanmamış Doktora Tezi. İstanbul: Yıldız Teknik Üniversitesi, Sosyal Bilimler Enstitüsü.

Saracaloğlu, A. S., Karademir, Ç. A., Dinçer, B., ve Dedebali, N. C. (2017). Öğretmenlerin öğretme stilleri, özyeterlik ve iş doyumlarının belirlenmesi. Education Sciences, 12(1), 58-85.

Saracaloğlu, A. S., Dinçer, B., Dedebali, N. C., ve Dursun, F. (2011). Sınıf, fen ve teknoloji ile türkçe öğretmenlerin öğretme stillerinin incelenmesi. NWSA e-Journal of New World Sciences Academy, 6(3), 2314-2327.

Sarıtaş, E. ve Süral, S. (2010). Grasha-Reichmann öğrenme ve öğretme stili ölçeklerinin türkçe uyarlama çalışması. E-Journal of New World Sciences Academy, 5(4), 2162-2177.

Şentürk, F. (2010). 7. Sını öğrencilerinin öğrenme stilleri ile matematik öğretmenlerinin öğretme stillerinin öğrencilerin matematik dersi başarısı üzerine etkisi. Yayımlanmamış Yüksek Lisans Tezi. Balıkesir: Balıkesir Üniversitesi, Fen Bilimleri Enstitüsü.

Şentürk, F., Ikikardeş, Y. N. (2011). Öğrenme ve öğretme stillerinin 7. sınıf öğrencilerinin matematik başarısı üzerine etkisi. Balıkesir Üniversitesi Necatibey Eğitim Fakültesi Elektronik Fen ve Matematik Dergisi, 5(1), 250-276.

Üredi, L.,ve Üredi, I. (2007). Sınıf öğretmenlerinin tercih ettikleri öğretim stillerinin yordayıcısı olarak öğretmenlik mesleğine ilişkin algıları. Mersin Üniversitesi Eğitim Fakültesi Dergisi, 3(2), 133-144.

Woolfolk, A. (1998). Educatinal psychology, (7th ed.). Boston: Allyn and Bacon.

Valeria, J. R. (2006). Educational backgrounds and teaching styles of athletic training educators in entry-level CAAHEP accredited athletic training programs. Doctoral Dissertation, University of South Florida, United States, UMI Number: 3240415

Türkoğlu, A. ve Süral, S. (2011). Ortaöğretimdeki öğretmenlerin öğretme stillerinin farklı değişkenler ile incelenmesi. 20. Ulusal Eğitim Bilimleri Kurultayı'nda sunuldu, Mehmet Akif Üniversitesi Eğitim Fakültesi, Burdur. 